\title{
水军動物肝臟のビタミンに關する研究（第6 報)
}

シアノーゲン・ブロマイド法に依るニコチン酸の比色定量法に就て(其の2)

束秀雄，平井正夫

（水㡾 試 驗 場）

昭和 18 年 5 月 29 日受理

诺者等は前報に於て純ニコチン酸水溶液を試料としてシアノーゲン・ブロマイド法に必要なる諸

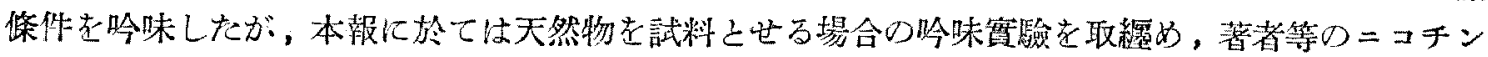
酸比色定量法老沚定し報告する。

(1) ニコチン酸の量と關係なき可溶性色素 ニさチン酸の量と關係なき可溶性色素は比色定量

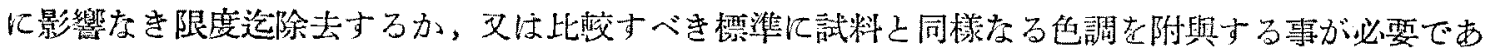

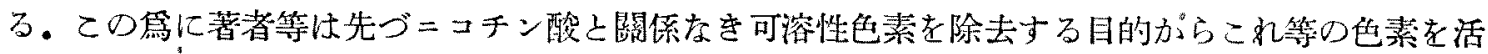

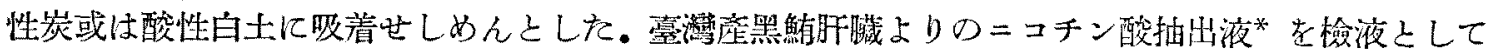

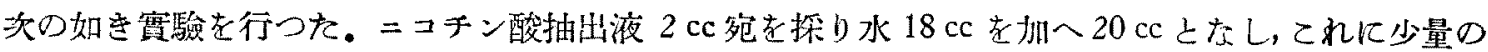

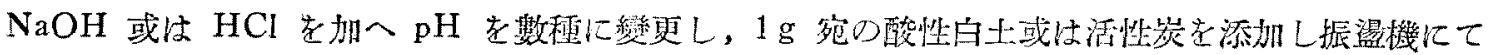

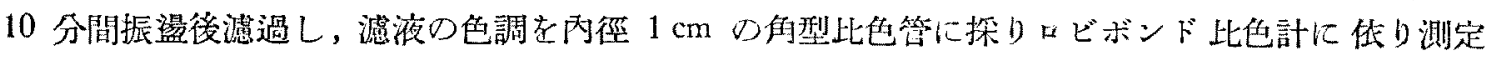
せるに第 13 表の如き絬果を得た。

\begin{tabular}{|c|c|c|c|c|}
\hline & 第 & 13 & & 第 13 裴に於て $\mathrm{pH} 4$ の場合に特に淡色となれるは反應液 \\
\hline \multirow{2}{*}{$\begin{array}{c}\text { 調㧘せる } \\
\text { pH }\end{array}$} & \multirow{2}{*}{ 添加せる } & \multicolumn{2}{|c|}{ 吸着處理後の色調 } & 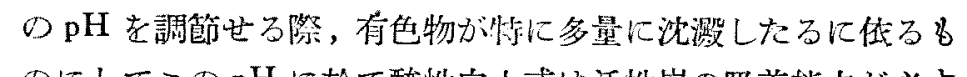 \\
\hline & & 黃色度 & 苏色度 & \\
\hline 2 & 酸性白土 & 2.50 & 0.77 & 性白土或は活性燹處理を行ふ時は相當脫色せられるが，份脫色 \\
\hline 4 & " & 0.38 & 0.05 & 不充分であり，且つ酸性に於て斯かる處理走行ふ事はニコチン \\
\hline 6 & $"$ & $\begin{array}{l}2.76 \\
3.50\end{array}$ & $\begin{array}{l}0.20 \\
0.86\end{array}$ & 量法に打 \\
\hline 8.5 & " & $6.2 n$ & 1.83 & 壮承 \\
\hline 9.5 & "l & 10.00 & 3.00 & WAISMAN 及び Elvehjem(1) は酒精溶 \\
\hline 2 & 活 性 宸 & 6.65 & 3.00 & 巴出子 \\
\hline 4 & $" \prime$ & 3.50 & 0.90 & D含量之關係奆可溶性色素を吸着除去する方 \\
\hline 6 & $"$ & 10.70 & 3.60 & 法よりも密る SWAMINATHAN(きの施行せる如く=コチン酸より \\
\hline 7 & $"$. & 10.82 & 3.60 & の生成色素をイソアミルアルコールにて抽出せんとした。 \\
\hline 8.5 & " & 12.80 & 4.00 & 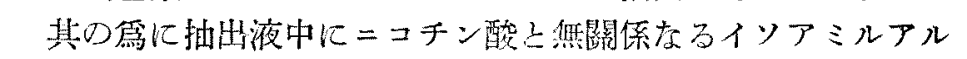 \\
\hline 9.5 & $\prime \prime$ & 12.00 & 3.60 & 了必要直認め，知の如き \\
\hline 8.5 & 無 添 加 & 13.72 & 3.30 & $\mathrm{cc}$ 泟水 $18 \mathrm{cc}$ 老加八 $20 \mathrm{cc}$ 上な \\
\hline
\end{tabular}

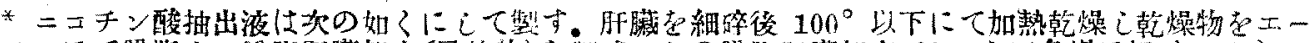

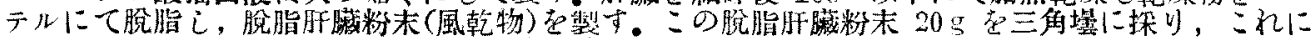

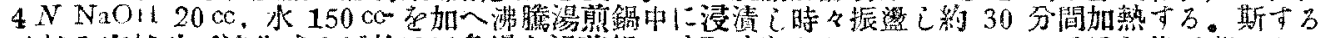

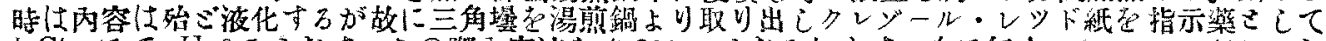

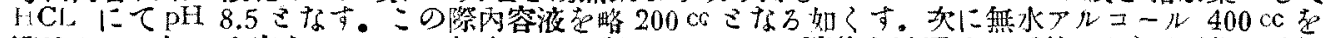

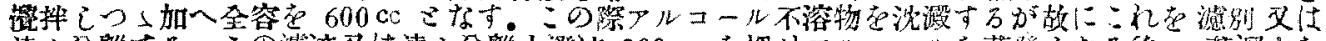

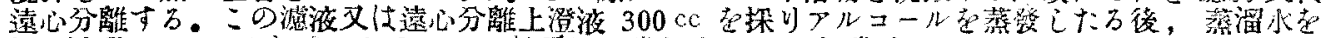

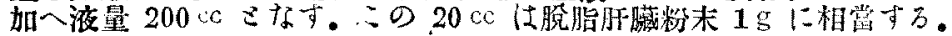

(1) H.A.Watsman and C.A.Elvehjem: J. Ind. Eng. Chem. (Anal)., 13 (1941). 221.

(2) M.Swaminathan: Nature, 141 (1938) 830. 
分液漏斗に採りこれにイソアミルアルコール $10 \mathrm{cc}$ を添加し，激しく 1 分間振埄後分離せるイソア

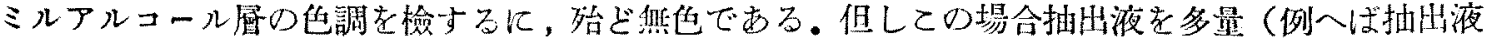

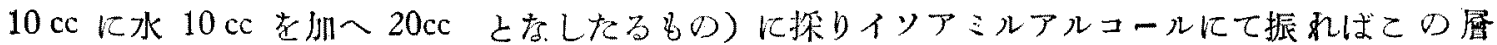

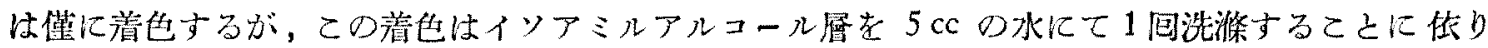

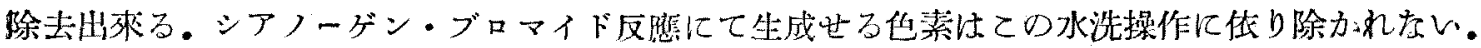

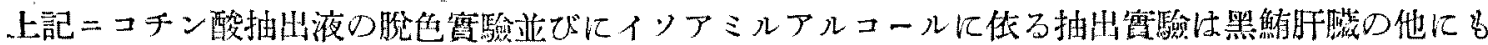

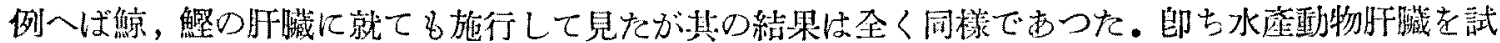
料とせる場合にはイソアミルアルコールを抽出劑として使肘すればニコチン酸と關係なき色素に依 る障密は炛か狆得る。

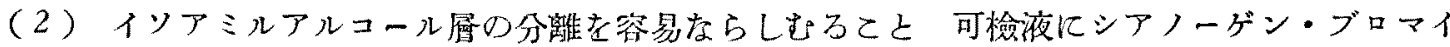
ド應在施行し，其の反應㴕より生成色秦をイソアミルアルコールを以て抽出するに際し，往々强固

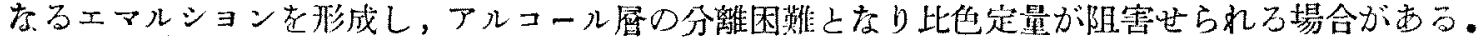

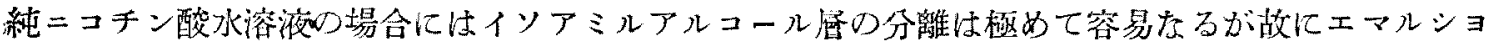
ン形成はニコチン酸以外の不純物に基因するものと認められる。從つてニコチン酸を椇失せしむる

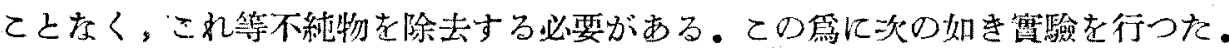

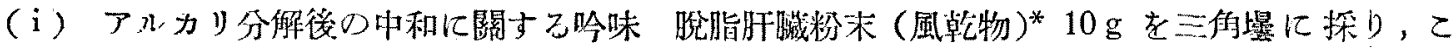

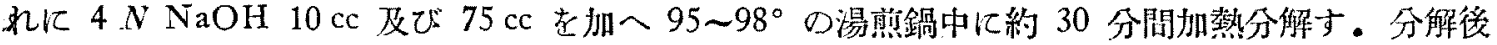
蒸溜水にて全液量を $90 \mathrm{cc}$ をす。の溶液 $18 \mathrm{cc}$ を探り $\mathrm{HCl}$ にて pH を調整後 $20 \mathrm{cc}$ を厉し，

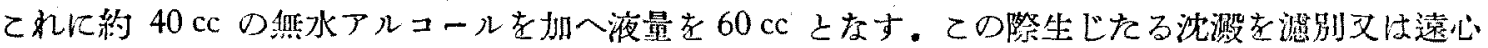

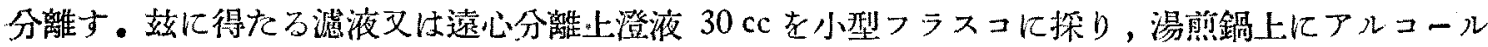

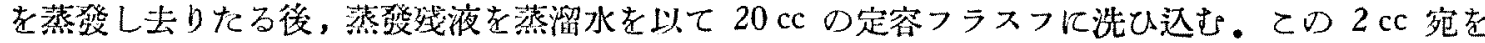

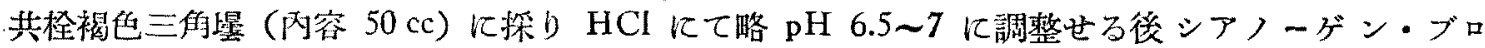

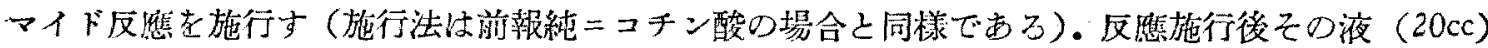
ルイソアミルアルコール10 cc 老加へ 1 分間激しく振りたる後，直に內容液を小型分液湿斗に梨 し, 移行後水溶液とイソアミルアルコール層との分離に要する時間を测定し, 兩首の分離の難易を

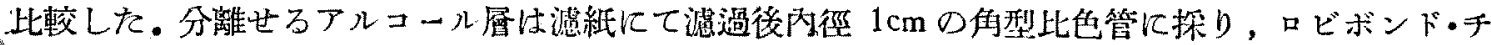
ントメーターに依り鲗色度を测定する。其の絬果は第14表の如くである。

第. 14 表

\begin{tabular}{|c|c|c|c|c|c|c|}
\hline \multirow{2}{*}{ 反憵液星 } & \multirow{2}{*}{\multicolumn{2}{|c|}{ 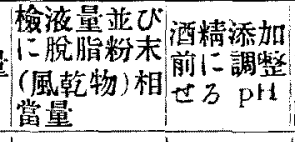 }} & \multirow{2}{*}{ 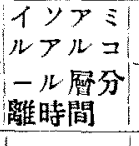 } & \multicolumn{2}{|c|}{ 呈 色 度 } & \multirow{2}{*}{$\begin{array}{l}\text { 試料100g } \\
\text { 中檢出さ } \\
3=z 7 \\
\text { 万酸量 }\end{array}$} \\
\hline & & & & 续色度 & 赤色度 & \\
\hline \multirow{5}{*}{$\cdot 20 \mathrm{cc}$} & \multirow{5}{*}{$\begin{array}{c}20 \mathrm{cc} \\
(100 \mathrm{mg})\end{array}$} & 2.0 & 15秒 & 0.67 & 0.05 & $23.9 \mathrm{mg}$ \\
\hline & & 4.0 & 17 & 1.04 & 0.05 & 29.5 \\
\hline & & 7.0 & 20 & 1.39 & 0.24 & 33.7 \\
\hline & & 8.5 & 27 & 2.90 & 0.45 & 57.8 \\
\hline & & 9.5 & 29 & 2.00 & 0.24 & 44.1 \\
\hline
\end{tabular}

第 14 表の結果得る如くアルカ リ分解後アルコールにて沈澱せしむ ろ場合，其の溶液老酸性となす時は イソアミルアルコール展の分離は多 少速か在れどもニコチン酸をる一部 沈測せしめる絬果さなる。故に著者 等は中性及び酸性に於てアルコール に依り沈澱せしさる事老避け，アル カリ性に効てアルコールにて沈澱せ

しさるカ法を探用した。例しアルカリ性に於てアルコールにて沈測せしむるのみでは試料の種類に

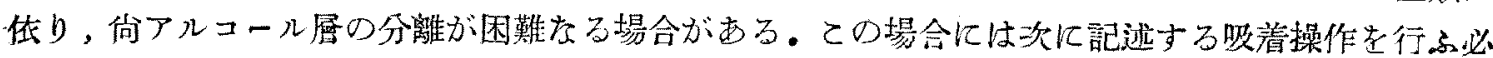
琶がある。 


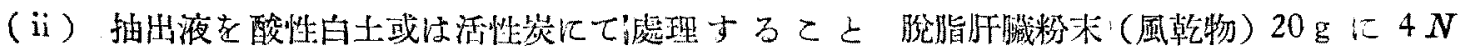
$\mathrm{NaOH} 20 \mathrm{cc}$, 水 $150 \mathrm{cc}$ 老加人上述如〈分解し, 乙れを $\mathrm{pH} 8.5$ となし更に水にて容量 $200 \mathrm{cc}$

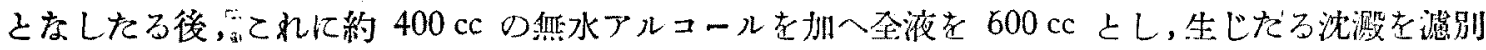

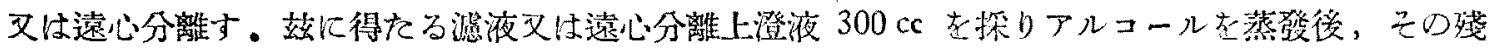
液在蒸溜水在以て $200 \mathrm{cc}$ の定容フラスコに洗ひ込む。 $2020 \mathrm{cc}$ 宛在探り $\mathrm{HCl}$ 或は $\mathrm{HaOH} に$

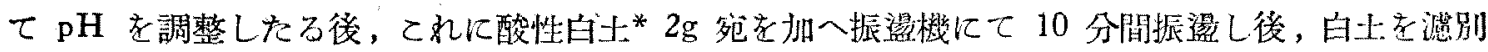

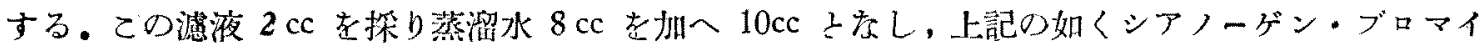
ド反㷳を施行し後，10ccのイソアミルアルコールを添加振望したるに第 15 裴の如を結果索得た。

\begin{tabular}{|c|c|c|c|c|c|c|c|}
\hline \multirow{2}{*}{$\begin{array}{c}\text { 反應液量 } \\
\text { (cc) }\end{array}$} & \multirow{2}{*}{ 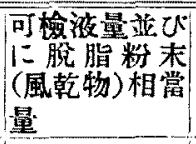 } & \multirow{2}{*}{$\begin{array}{l}\text { 酸性白士添 } \\
\text { 加前に調整 } \\
\text { ぜ } \mathrm{pH}\end{array}$} & \multirow{2}{*}{$\begin{array}{c}\text { 酸性白士 } \\
\text { 稀 加 量 } \\
\text { (g) }\end{array}$} & \multirow{2}{*}{ 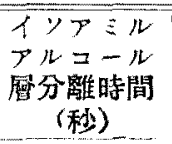 } & 呈 & 度 & \multirow{2}{*}{ 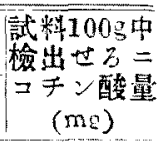 } \\
\hline & & & & & 黄色度 & 赤色度 & \\
\hline \multirow{4}{*}{20} & \multirow{4}{*}{$\begin{array}{c}2 c c \\
(100 \mathrm{mg})\end{array}$} & 4.0 & 2 & 15 & 0.65 & 0.05 & 23.6 \\
\hline & & 7.9 & 2 & 17 & 2.24 & 0.46 & 47.7 \\
\hline & & 8.5 & 2 & 20 & 2.65 & 0.57 & 54.0 \\
\hline & & 9.5 & 2 & 25 & 2.90 & 0.57 & 57.8 \\
\hline
\end{tabular}

第 15 表の結果に見る如く酸性白土處理に依りアルコール居の分離は何れる容易となる。併し酸 性に於ては不純物と共に二コチン酸の吸着も行はれるから不純物の除去法として, 酸性白土處理を 行ふ場合にはアルカリ性に於て施行する必要がある。著者等は更にアルカリ性に於て酸性白土吸着 處理吉行ふ際の酸性白土使用量几就吟味を行つた。郎ち上記ニコチン酸抽出液を $\mathrm{pH} 9.5$ に調整

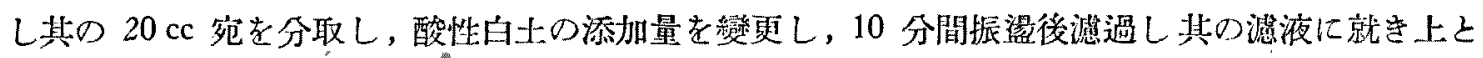
同樣なる惯驗を行つた。其の結果を取縓め第 16 裴に揭げる。

第 16 表

\begin{tabular}{|c|c|c|c|c|c|c|c|}
\hline \multirow{2}{*}{$\begin{array}{c}\text { 反膲液量 } \\
(\mathrm{cc})\end{array}$} & \multirow{2}{*}{ 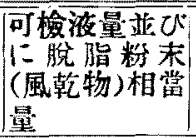 } & \multirow{2}{*}{$\begin{array}{c}\text { 酸性白士 } \\
\text { 添 加量 } \\
(\mathrm{g})\end{array}$} & \multirow{2}{*}{$\begin{array}{l}\text { 酸性白土處 } \\
\text { 理後の pH }\end{array}$} & \multirow{2}{*}{ 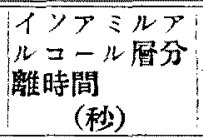 } & \multicolumn{2}{|c|}{ 色 } & \multirow{2}{*}{ 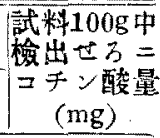 } \\
\hline & & & & & 黄色度 & 赤色度 & \\
\hline \multirow{8}{*}{20} & \multirow{8}{*}{$\begin{array}{c}2 \mathrm{cc} \\
(100 \mathrm{mg})\end{array}$} & 0 & $=$ & 27 & 2.90 & 0.45 & 57.8 \\
\hline & & 0.5 & 8.4 & 25 & 2.90 & 0.45 & 57.8 \\
\hline & & 1.0 & 8.8 & 25 & 2.90 & 0.64 & 57.8 \\
\hline & & 1.5 & 8.2 & 25 & 2.90 & 0.64 & 57.8 \\
\hline & & 2.0 & 8.0 & 23 & 2.90 & 0.64 & 57.8 \\
\hline & & 2.5 & 7.8 & 20 & 2.80 & 0.58 & 56.3 \\
\hline & & 3.0 & 7.2 & 17 & 2.80 & 0.58 & 56.3 \\
\hline & & 4.0 & 7.0 & 17 & 2.50 & 0.58 & 51.7 \\
\hline
\end{tabular}

第 16 表の結果に見る如く酸性白土添加量を増すと共に分離洔間は短縮し，溶液の反應は中性に 移行し，白土使用量 $4 \mathrm{~g}$ の場合は滤液は $\mathrm{pH} 7$ となりニコチン酸の吸着が認められる。

以上の兾驗に敒りイソアミルアルコール首の分離を容易にする方法として，アルカリ性に於て適 量の酸性白土にて處理し，不純物支除去する方法が有效であることが分る。但し酸性白土使用の際

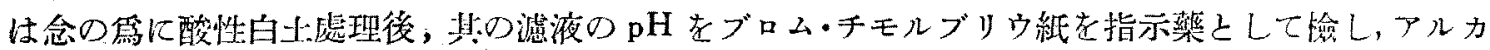

* 酸性白土及び活性峞仿前報の (4) 項の趴註參照。 


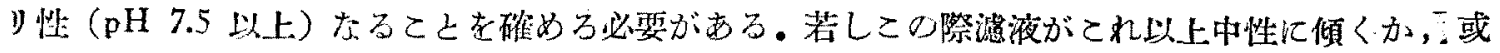
は酸性之なりたる場合江酸性白土使用量を減じなりればなら好。

沃に著者等は不純物吸着實駿を酸性白土の代りに活性炭*老使用して施行して見て。其の結果を 第 17 及び 18 泰に取継める（試料並びに宽驗操作は上記酸性白土の場合と全く同椂にした）。

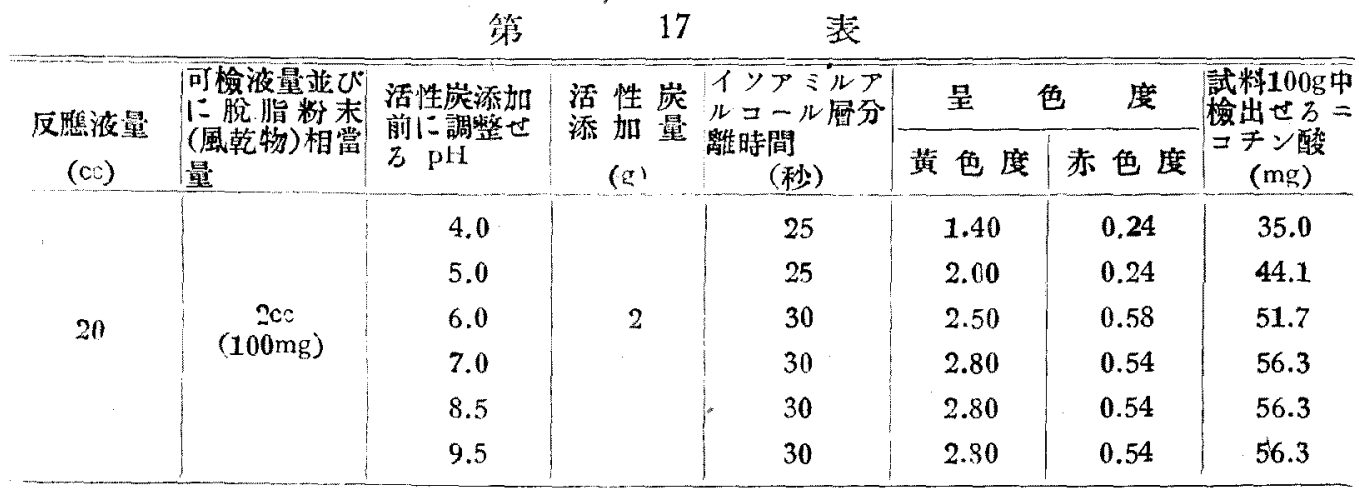

第 18 表

\begin{tabular}{|c|c|c|c|c|c|c|c|}
\hline \multirow{2}{*}{$\begin{array}{c}\text { 反熊液量 } \\
(c c)\end{array}$} & \multirow{2}{*}{ 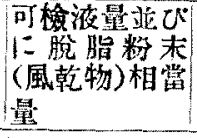 } & \multirow{2}{*}{$\begin{array}{c}\text { 活 性宸 } \\
\text { 蒸加量 } \\
(\mathrm{g})\end{array}$} & \multirow{2}{*}{$\begin{array}{l}\text { 活性逤處理 } \\
\text { 淩の } \mathrm{pH}\end{array}$} & \multirow{2}{*}{ 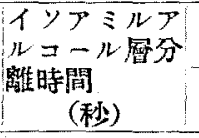 } & \multicolumn{2}{|c|}{ 呈 色 } & \multirow{2}{*}{ 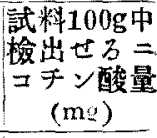 } \\
\hline & & & & & 黄色度 & 浾色度 & \\
\hline \multirow{7}{*}{20} & \multirow{7}{*}{$\begin{array}{c}2 c c \\
(100 \mathrm{mg})\end{array}$} & 0.5 & 9.1 & 30 & 2.80 & 0.50 & 56.3 \\
\hline & & 1.0 & 9.1 & 30 & 2.80 & 0.50 & 56.3 \\
\hline & & 1.5 & 9.1 & 30 & 2.80 & 0.50 & 56.3 \\
\hline & & 2.0 & 9.1 & 30 & 2.80 & 0.50 & 56.3 \\
\hline & & 2.5 & 9.2 & 25 & 2.50 & .0 .50 & 51.7 \\
\hline & & .3 .0 & 9.2 & 25 & 2.50 & 0.50 & - 51.7 \\
\hline & & 5.0 & 9.2 & 20 & 2.30 & 0.50 & 48.7 \\
\hline
\end{tabular}

一第 17 及び 18 表の結果より見れば不純物吸着の目的に活性炭を使用せる場合はアルカリ性に於 てはニコチン酸吸着せられ損失することなき（但し純ニコチン酸水溶液の場合に於ては前報の

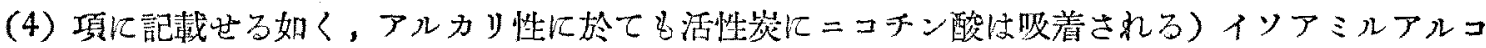

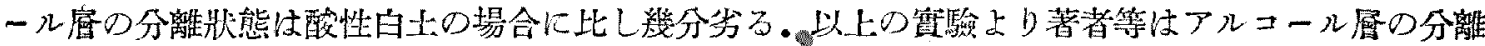

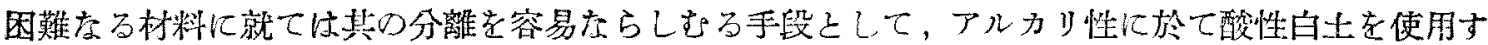
ろてと〉した。

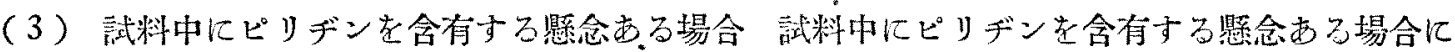
は先づ脫脂粉末 (風乾物) をせる試料 $2 \mathrm{~g}$ をフラスコに採り， $4 \mathrm{~N} \mathrm{NaOH} 2 \mathrm{cc}$ を加へ $100^{\circ}$ に加

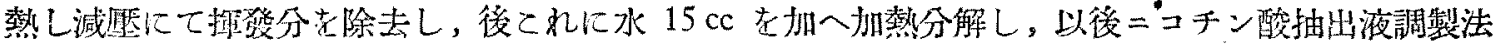
〔(1)項，脚註參照〕に從ひ可檢液孛調製する。この操作に低りピリヂン老除去することが出來る。

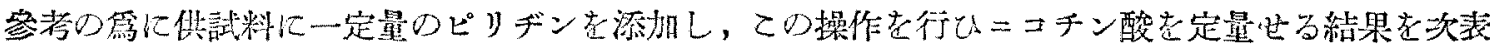
に示す。

\begin{tabular}{|c|c|c|c|c|c|c|c|c|}
\hline & & 第 & 19 & 表 & & & & \\
\hline 處 & 理 & 法 & 誡料控取 & ピりギy & 脽液量 & 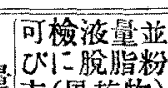 & & 度色 \\
\hline & & & $\begin{array}{l}\text { (風 } \\
\text { (乾) }\end{array}$ & $(\mathrm{mg})$ & (cc) & $\begin{array}{l}\text { 米(風乾物) } \\
\text { 相賞 }\end{array}$ & 黄度 & 赤色梦 \\
\hline 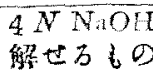 & 及水 1 & 加已加熱分 & 2 & 0 & $20 \mathrm{cc}$ & $\begin{array}{c}2 \mathrm{cc} \\
(100 \mathrm{mg})\end{array}$ & 2.90 & 0.64 \\
\hline
\end{tabular}




\begin{tabular}{|c|c|c|c|c|c|c|}
\hline 同 & \multirow{3}{*}{2} & 3 & \multirow{3}{*}{$200 \mathrm{c}$} & \multirow{3}{*}{$\begin{array}{c}2 \mathrm{cc} \\
(100 \mathrm{mg})\end{array}$} & 3.50 & 0.92 \\
\hline 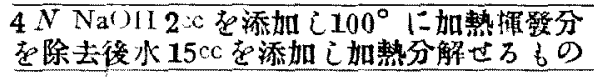 & & 0 & & & 2.90 & 0.64 \\
\hline 同 & & 3 & & & 2.90 & 0.72 \\
\hline
\end{tabular}

上表の如く添加せるピリヂンは完全に除去せられる。

（4）著者等のニコチン酸比色定量法 以上に低りシアノーゲン・ブロマイド法化化る比色定量

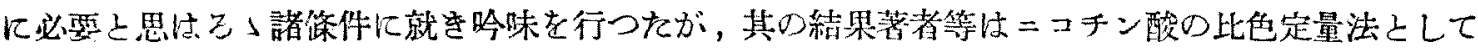
夾の方法を探用すること〉した。

(i) 檢液の調製法 (a) 固體試料の場合 試料老紐碎乾燥しエーテルにて脫脂し脫脂粉末（風

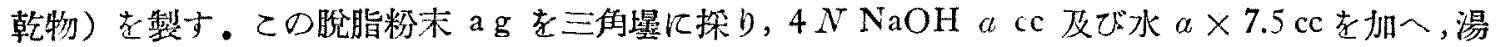

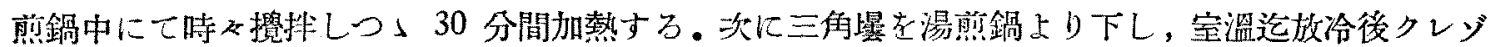

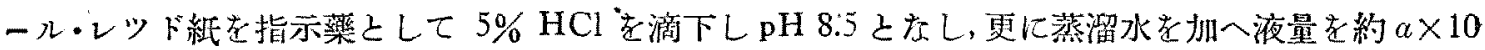

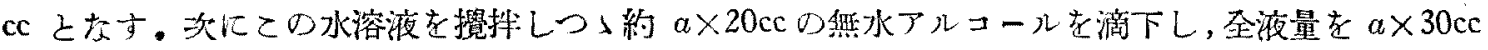

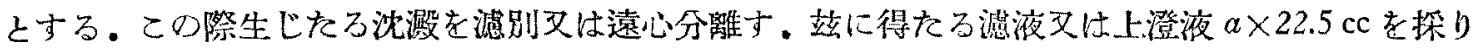
湯煎鍋上にアルコールを蒸發し，殘液に蒸溜水を加へ $a \times 15 \mathrm{cc}$ とし可檢液とす(但しシア)ーダ ン・ブ日マイド反應施行後, 生成色素をイソアミルアルコールにて抽出する際のアルコール首の分 離困難去る場合は，乙の可檢液 $\alpha \times 10 \mathrm{cc}$ を共栓三角嚗に探り $\mathrm{pH} 9.5$ となしてれに適量の酸性白

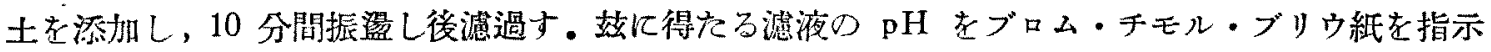

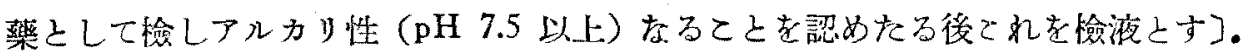

（b）試料が水溶液なる場合 試料が水溶液上なる場合怙てれに直に $1 / 4$ 容の $4 \mathrm{~N} \mathrm{NaOH}$ を 加へてアルカリ分解を行ひ，次に上述操作と同樣に施行すればよい.

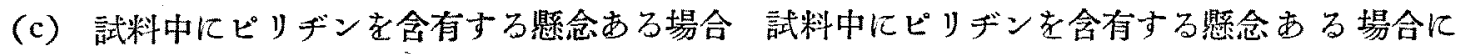

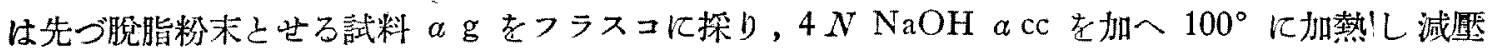
にて揮發分老除去し，後てれに水 $a \times 7.5 \mathrm{cc}$ を加へ加熱分解し，以後（a）固體試料の場合に從ひ 可檢液を調撆する。

（ii）シアノーダン・ブロマイド反應の施行法並ざに生成色素の比色法 上記可檢液 $a$ cc 宛を 8 個の小型共柽三角嚗(內容 $50 \mathrm{cc}$ ) 反分取し，各々に $(10-a) \mathrm{cc}$ 宛の水老添加し略 $\mathrm{pH} 6.5 \sim 7 \mathrm{~K}$

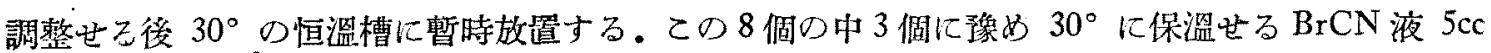

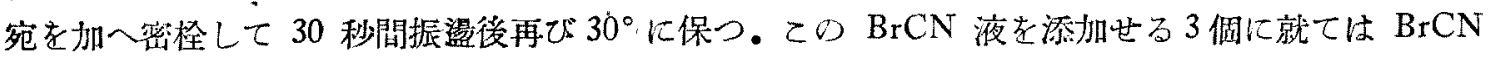
液作用時間を夫 3 分, 5 分, 15 分の如くし，後アリニン液 $5 \mathrm{cc}$ 宛䘮涯加後，5 分にして精製

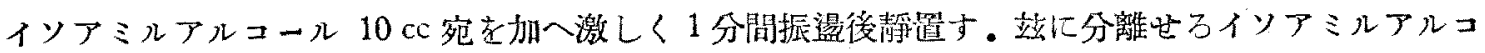

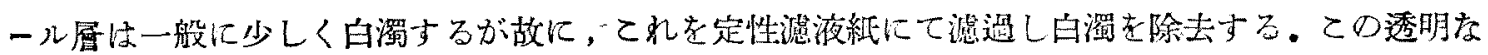
る滤液を內徑 $1 \mathrm{~cm}$ の角型比色管に探り，口ビボンド・チントメーターにて其の革色度を测定す

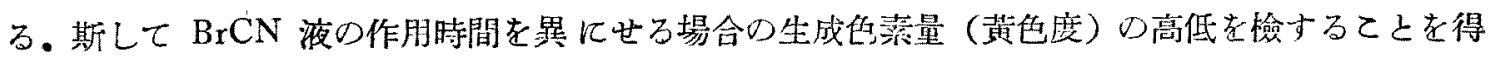
るが故に，殘りの5 個の可檢液に就其の $\mathrm{BrCN}$ 液作用時間老調節し，最高の生成色素量（黄色 度）を得る如くシアノーダン・ブロマイド反應を施行し，10 cc 宛のイソアミルアルコールにて生 成色素を抽出し比色する。斯して得をるイソアミルアルコール扈の最高黄色度（y）より前報第 2

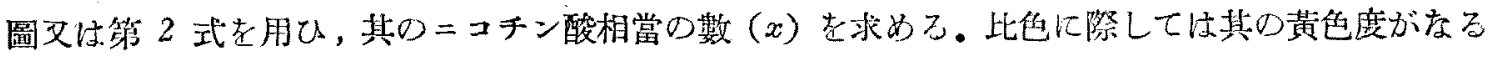

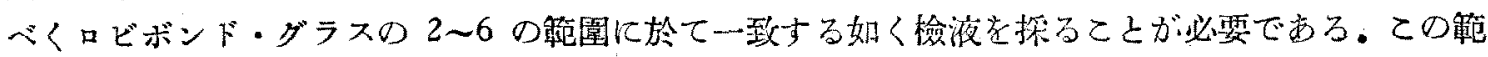
圍以上濃厚或忙稀薄なる場合は測定が不正確となる。 


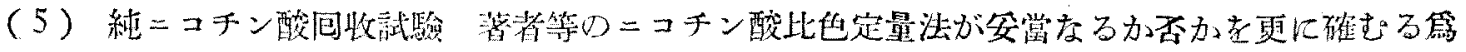

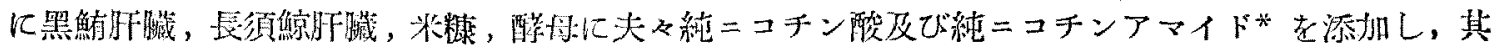
のニコチン酸荙定量し，添加ニコチン酸回收率在檢したるに第 20 及び 21 关の如き結果を得を。

符 20 表

\begin{tabular}{|c|c|c|c|c|c|c|c|c|}
\hline \multirow{2}{*}{ 試粹名程 } & \multirow{2}{*}{ 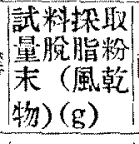 } & \multirow{2}{*}{$\begin{array}{c}=\text { 二 } \\
\text { 酸添加䲝 } \\
(i)\end{array}$} & \multirow{2}{*}{ 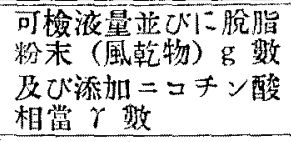 } & \multicolumn{2}{|c|}{ 呈 他 度 } & \multirow{2}{*}{ 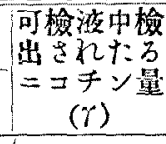 } & \multirow{2}{*}{ 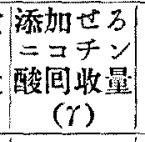 } & \multirow{2}{*}{ 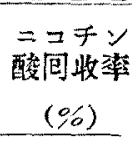 } \\
\hline & & & & 黄色度 & 赤色度 & & & \\
\hline 黑 鮁 & \multirow{8}{*}{2} & 0 & $\begin{array}{c}2 \mathrm{cc} \\
(0.1 \mathrm{~g})\end{array}$ & 2.90 & 0.60 & 57.8 & & \\
\hline 朋 臟 & & 250 & $\begin{array}{c}2 c c \\
(0.15+12.5 \gamma)\end{array}$ & 3.70 & 0.70 & 69.9 & 12.1 & 96.8 \\
\hline 長須䑸 & & 0 & $\begin{array}{l}2 \mathrm{cc} \\
(0.1 \mathrm{~g})\end{array}$ & 2.75 & 0.05 & 55.5 & & \\
\hline 旰臟 & & 250 & $\begin{array}{c}2 c c \\
(0.1 g+12.5 \gamma)\end{array}$ & 3.55 & 0.55 & 67.7 & 12.2 & 97.6 \\
\hline \multirow{2}{*}{ 米 䆂 } & & 0 & $\begin{array}{c}2 c c \\
(0.1 \mathrm{~g})\end{array}$ & 2.25 & 0.55 & 47.9 & & \\
\hline & & 250 & $\begin{array}{c}2 c c \\
(0.1 g+12.5 \gamma) \\
\end{array}$ & 3.05 & 0.55 & 60.1 & 12.2 & 97.6 \\
\hline \multirow{2}{*}{ 醳 } & & 0 & $\begin{array}{c}2 \mathrm{cc} \\
(0.1 \mathrm{~g})\end{array}$ & 3.00 & 0.24 & 59.3 & & " \\
\hline & & 250 & $\begin{array}{c}2 c c \\
(0.1 g+12.5 \gamma)\end{array}$ & 3.78 & 0.24 & 71.2 & 11.9 & 96.0 \\
\hline
\end{tabular}

第 $21 \quad$ 表

\begin{tabular}{|c|c|c|c|c|c|c|c|c|}
\hline \multirow{2}{*}{ 試料名稱 } & \multirow{2}{*}{ 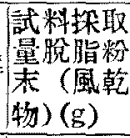 } & \multirow{2}{*}{ 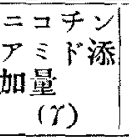 } & \multirow{2}{*}{ 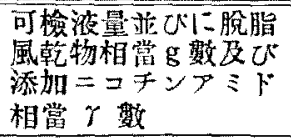 } & \multicolumn{2}{|c|}{ 呈 色 库 } & \multirow{2}{*}{\multicolumn{2}{|c|}{ 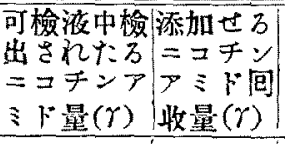 }} & \multirow{2}{*}{ 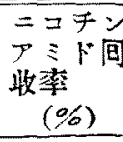 } \\
\hline & & & & 黄色度 & 赤色度 & & & \\
\hline 黑 䰹 & \multirow{8}{*}{2} & 0 & $\begin{array}{c}2 \mathrm{cc} \\
(0.1 \mathrm{~g})\end{array}$ & 2.90 & 0.60 & 57.8 & & \\
\hline 肝 萑 & & 250 & $\begin{array}{c}2, c c \\
(0.1 g+12.5 \gamma)\end{array}$ & 3.77 & 0.60 & 71.0 & 13.2 & 105,0 \\
\hline 長須触 & & 0 & $\begin{array}{c}2 c c \\
(0.1 g)\end{array}$ & 2.75 & 0.50 & 55.5 & & \\
\hline 肝 藏 & & 250 & $\begin{array}{c}2 c c \\
(0.1 g+12.5 \gamma)\end{array}$ & 3.56 & 0.50 & 67.9 & 12.4 & 99.2 \\
\hline \multirow{2}{*}{ 米 糠 } & & 0 & $\begin{array}{c}2 \mathrm{cs} \\
(0.1 \mathrm{~g})\end{array}$ & 2.25 & 0.50 & 47.9 & & \\
\hline & & 250 & $\begin{array}{c}2 c c \\
(0.1 g+12.5 r)\end{array}$ & 3.05 & 0.70 & 60.1 & 12.2 & 97.6 \\
\hline \multirow{2}{*}{ 醇 } & & 0 & $\begin{array}{c}2 c c \\
(0.1 g)\end{array}$ & 3.00 & 0.20 & 59.3 & & \\
\hline & & 250 & $\begin{array}{c}2 \mathrm{cc} \\
(0.1 \mathrm{~g}+12.5 r)\end{array}$ & 3.80 & 0.50 & 71.5 & 12.2 & 97.6 \\
\hline
\end{tabular}

第 20 及び 21 表に見乃如く著者等の比色定量法に依り添加ニコチン酸及びニコチンアマイドは 96〜105\% 回收せられて居り，略滿足す心゙き結果が得られた。

（6）桨者等のニコチン酸比色定量法に依乃試料中のニコチン酸含量定量結果 (4)に記载せる

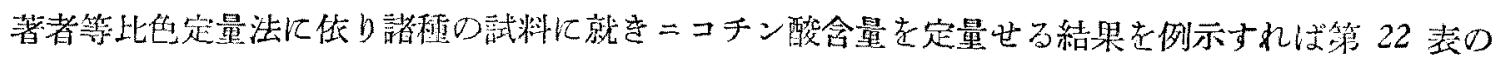
如くである。 


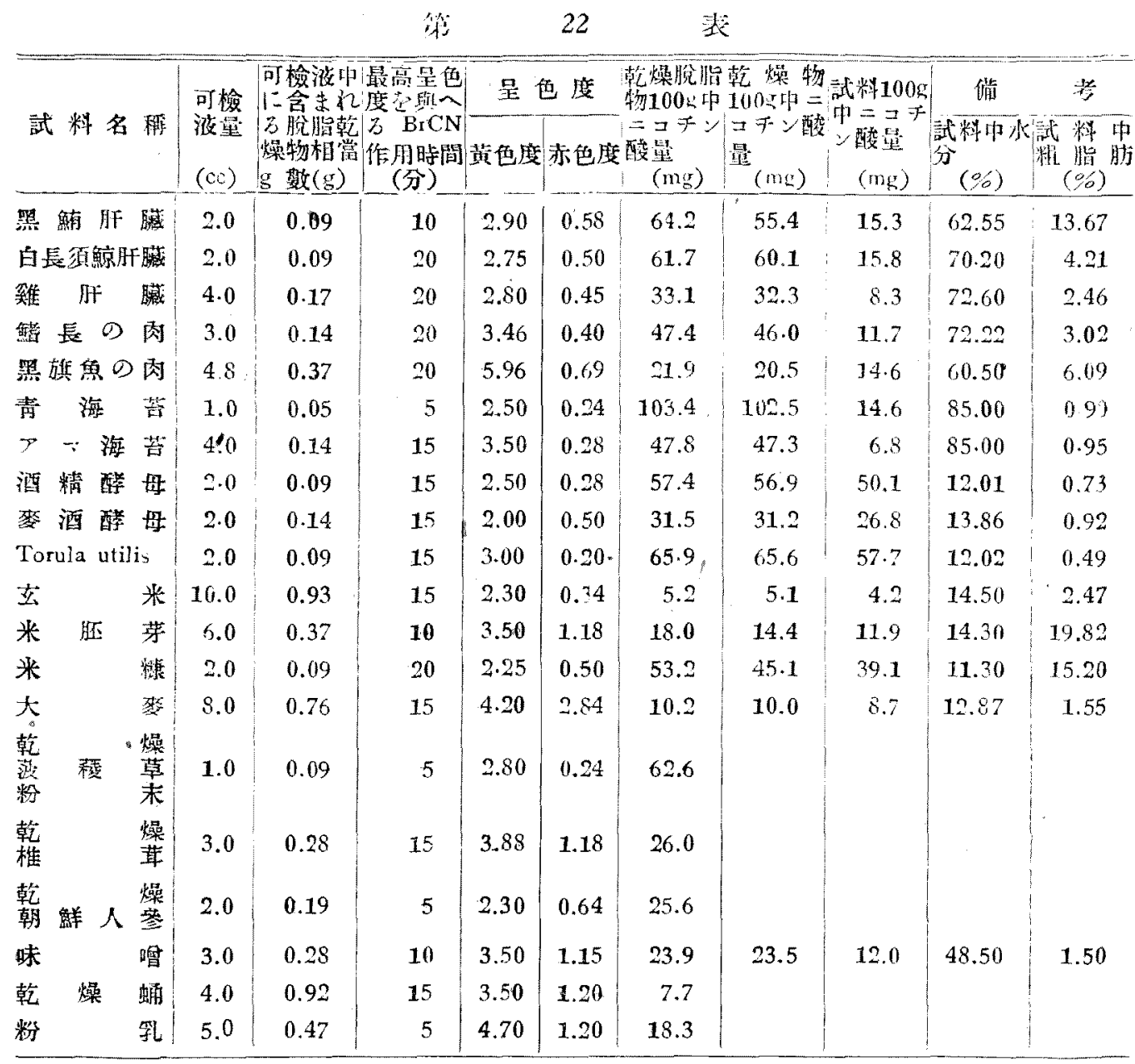

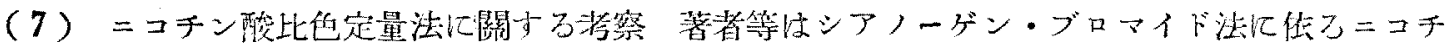

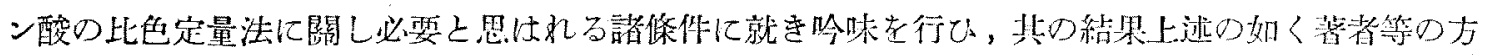

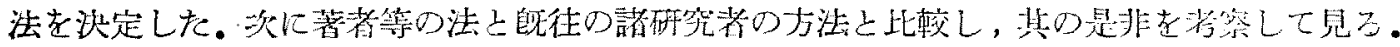

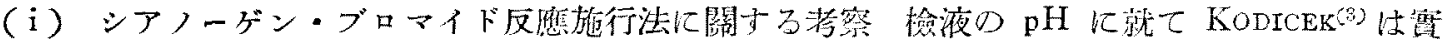

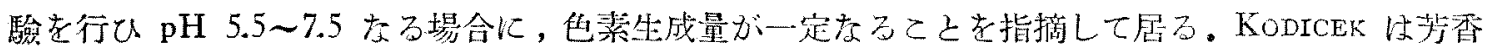
㵀アミンとして p-アミノアセトフェノンを使用して居るが，著者等の場合はアニリンを使用して

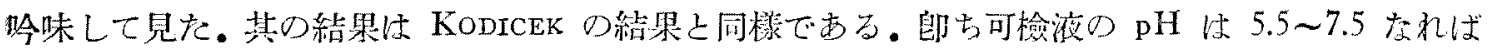

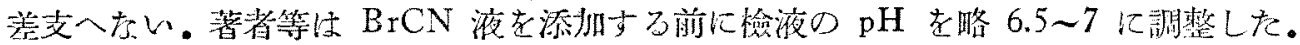

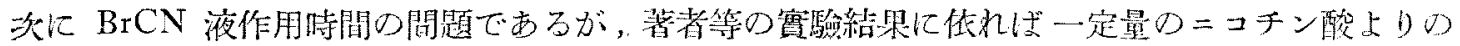

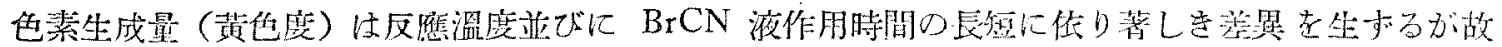

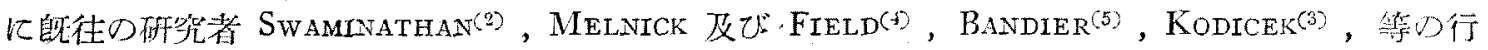

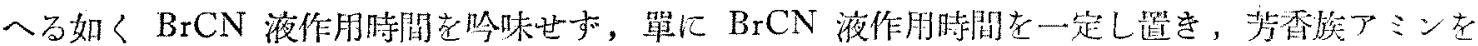

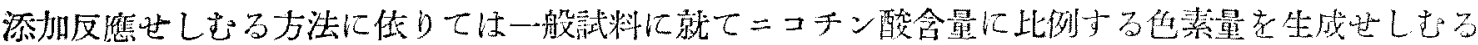

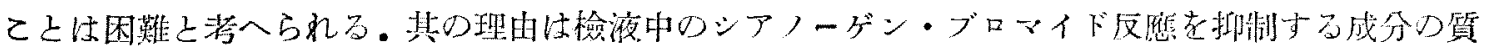




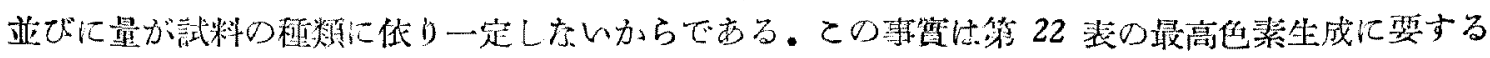

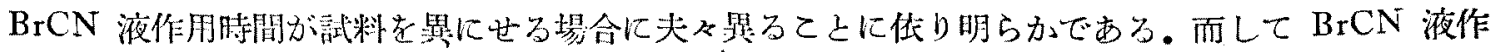

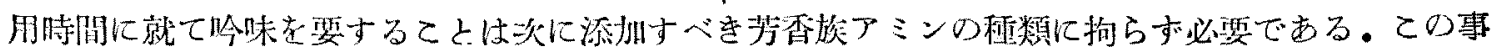

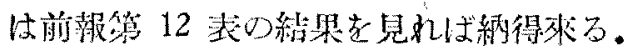

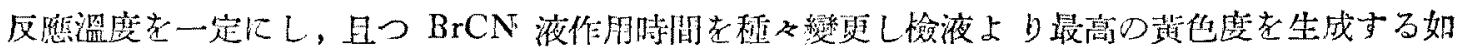
くシアノーダン・ブロマイド反應老行へば妿香族アミンとしてアニリン老使朋すア事つ不都合は認 められない。

HARRIS 及び RAYMQND ${ }^{(0)}$ ，KodiceK(3) 或は BANDIER 及び HALD(7)がアニリンよりもメトー 几或はアミノアセトフェノンがより好適であるとした理由は，夫ふの場合ひ $\mathrm{BrCN}$ 液作用時間を

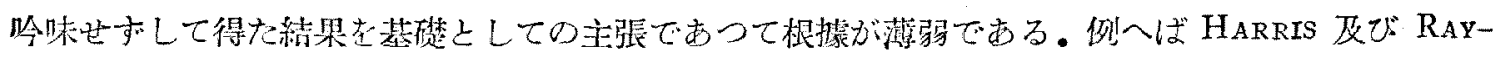
MOND(א) は $p$ アミノアセトフェノン老使用せる場合はメトール或はアニリンを使用せる場合の 5 倍

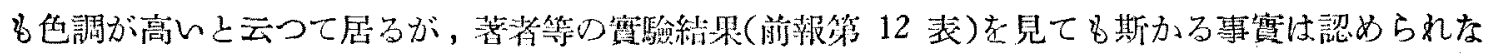
い.即ちHARRIS 等の實驗條件に於て斯かる結果が得られたに過ざないのである。著者等は使用す べき芳香族アミンに就て總べて考吟味した譯ではないが，使用可能にして且つ入手窑易なる點より SWAMINATHAN(

（ii）イソアミルアルコールの使用に就て 檢液の巴調㮁薄なる場合，或は脫色容易なる場合は 生成色素基の水溶液にて此色定量する事は可能であるが，可檢液の色調が著しく濃厚なる場合は

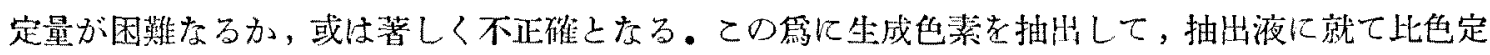
量を行ふ必要がある・シアノーケ゚ン・ブロマイド反應に依りニコチン酸から生成せる出素をイソフ ミルアルコール要以て抽出する事化て ASCHFORD 及び CLARK(9) は反對し, 叉 BANDIER 及で HALDはイソアミルアルコール中のビリヂン㤬精製て依り除去し難い之述べて居るが，蓄者等の

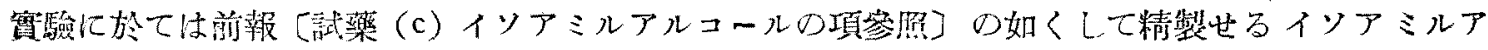

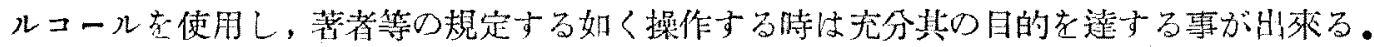

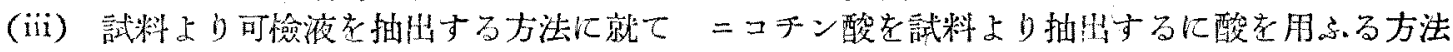

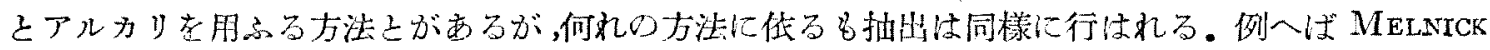

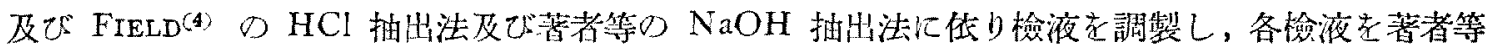
の方法に從つてシアノーダン・ブロマイド反應在施行し比色すれば其の結果は全く一玨する。兩抽

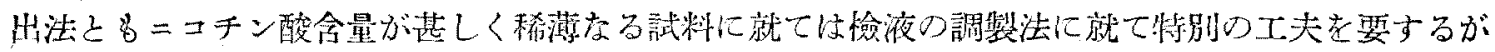
著者等名赏面の目的上せる試料に就ては何等の不都合至認めない。

試料中にピリヂン考含有せる場合は，著者等が憸液の調繁法 (c) 項に記述せる如き方法を探用す

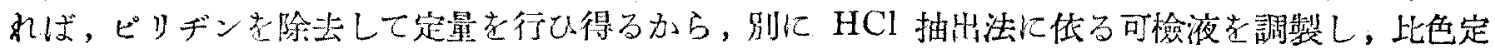
量索行へば試料中にピリデンの定星も可能であらう。

以上の諸點索綜合して著者等のニコチン酸比色定量法は著者等の目的上せ万水產動物試料化就て

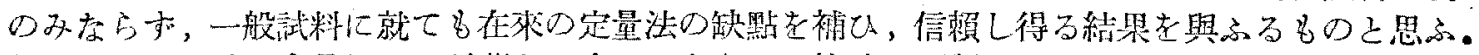

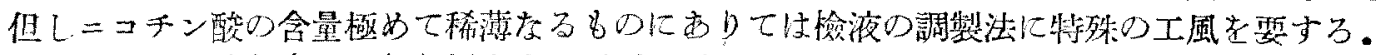

著者等住生成色素の此色を便宜上ロビボンド・チントメーターを使用して行つたが，刎論プルフ リツヒ或は LEIFO photometer 使用して测定する事も出隶る噿であるが，乙の際は别に純ニコチ

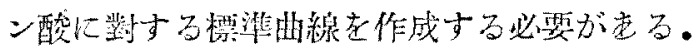

\section{(7) 摘}

要

シアノーグン・ブロマイド反應に依るニコチン酸の比色定量法に關し吟味實驗圭行ひ，既徍の諸

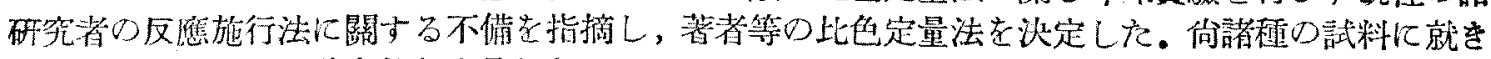
本法江仿りニコチン酸合量定定量した。

(6) L.T.Harris and W.D.RAYMond: Biochem.J., 33 (1939) 2037. (7) E.Bandier and

J.HALD: Biochem.J., 33 (1939) 264. (8) W.R.AsChFord and R.H.ClakK: C.A., 43, 6959. 